\title{
Status of Benzene, Toluene and Xylene near petrol pumps of Satna city M.P.
}

\section{${ }^{\mathrm{I}}$ Sadhana Chaurasia}

${ }^{2}$ Ashok Kumar Tiwari

\section{Tead, Dept. of Energy \& Environment, MGCGV, Chitrakoot, Satna MP.485331. \\ 2 Research Scholar, Dept. of Energy \& Environment, MGCGV, Chitrakoot, Satna MP.485331}

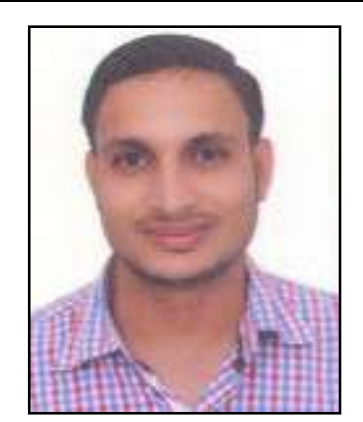

Corresponding author:

Ashok Kumar Tiwari $\underline{\text { tiwarichitrakoot@gmail.com }}$
Received: June 09, 2017

Revised: November 27, 2017

Published: December 30, 2017

\begin{abstract}
Benzene, Toluene and Xylene (BTX) are present in both exhaust and evaporative emission from vehicles and at the fuel delivery outlets in the urban atmosphere. The aim of the present study was to understand ambient air quality with respect to carcinogenic pollutants i.e. BTX (Benzene, Toluene and Xylene). Study was conducted in different petrol pumps at Satna city. Air samples were collected and analyzed as per CPCB guidelines/BIS Standards. BTX sample were analyzed using gas chromatograph (GC) fitted with capillary column and flame ionization detector (FID).
\end{abstract}

Benzene causes deleterious effects on human beings, therefore, it is a matter of concern that everyone should take immediate action to control VOCs especially BTX. These types of compounds once released in the environment, usually evaporate quickly into the air. The primary man made sources of BTX into the environment are via emissions from motor vehicles, losses during petrol marketing and cigarette smoke. In the present study benzene was found in the range of $2-12 \mu \mathrm{g} / \mathrm{m}^{3}$ and it was higher than the permissible limit prescribed by the $\mathrm{CPCB}$ is $5 \mu \mathrm{g} / \mathrm{m}^{3}$ for benzene and it may be cause of health concern.

Keywords- Atmosphere, AAQ, Benzene, Toluene and Xylene, GC-FID, Satna city. 


\section{INTRODUCTION}

Air pollution continues to receive a great deal of interest worldwide due to its negative impacts on human health and welfare. Air pollution and certain diseases including asthma, bronchitis, nausea, chest pain, lung cancer, shortness of breath and sore throat Agrawal and Khanam, (1997); Chaurasia and Tiwari (2016). Air toxics are air pollutants that cause adverse health effects. The U.S. Environmental Protection Agency has focused most of air toxics effect on carcinogens, which are compounds that cause cancer. Non-cancer health effects such as reproductive and neurological problems are also of concern. Automobile i.e. car, truck, and buses are the source of air toxics account for as much as half of all cancers attributed to outdoor sources of air toxics.

Motor vehicles emit several pollutants that classified as known or probable human carcinogens. Benzene, for instance, is a known human carcinogen while diesel and particulate matter is probable human carcinogen. A significant amount of automotive benzene comes from the incomplete combustion of compounds in gasoline such as toluene and xylene that are chemically very similar to benzene US EPA (1992). BTX are potentially toxic air pollutants among volatile organic compounds (VOCs) and has been subjected to significant investigations in India (Singh, Tomer and Jain, 2012). These compounds occur naturally in petroleum and become more concentrated when petroleum is refined to produce high octane gasoline.

Gasoline is the major source of benzene. Other sources include wood smoke and cigarette smoke. Some toxic compounds are present in gasoline and are emitted to the air when gasoline evaporates or passes through the engine as unburned fuel. Benzene, for example, is a component of gasoline. Cars emit small quantities of benzene in unburned fuel, or as vapor when gasoline evaporates. Formaldehyde, acetaldehyde, diesel particulate matter, and 1, 3-butadiene is not present in fuel but is by-products of incomplete combustion. Formaldehyde and acetaldehyde are also formed through a secondary process when other mobile source pollutants undergo chemical reactions in the atmosphere. The amount of VOC emissions is depending mainly processes used in petrol station, which were include loading and breathing of fuel storage tank as well as refueling. In general, emission could occur from vehicles operation inside the petrol filling stations and hot-soak as well as spills and leaks from fuel pipe line. Petrol stations distribute the VOCs into their surroundings environments (Eltahir et al., 2016).

\section{Study area}

The study area Satna is known as the cement city of India. It is situated at latitude 23"58' and 25"12' North; longitude 80 ' 21 'and 81 '23' East at an elevation of 317 meter above the mean sea level. The average rainfall is $817.6 \mathrm{~mm}$ per year maximum during monsoon months. It covers an area of 7502 square kilometer. Dominant wind direction is west to east. Satna is in the limestone belts of India. As a result, it contributes around $8 \%-9 \%$ of India's total cement production. There is abundance of dolomite and limestone in the area and the city has more than 07 cement factories producing and exporting cement to other parts of the country. Satna is connected to the longest National Highway: NH-7. State highway-75 passes from the heart of Satna. The city of Satna is known as the commercial capital of Baghelkhand. The city is among the few most promising cities of Madhya Pradesh because of the several new industries planned by some of the reputed industrial houses in the country. 


\section{Objective}

1. To determine particulate matter $\left(\mathrm{PM}_{10}\right.$ and $\left.\mathrm{PM}_{2.5}\right)$ in ambient air at selected locations of Satna city MP.

2. To determine gaseous pollutants $\left(\begin{array}{lll}\mathrm{SO}_{2} & \& & \mathrm{NO}_{\mathrm{x}}\end{array}\right)$ in ambient air at selected locations of Satna city MP.

3. To determine the Benzene, Toluene and Xylene concentration in ambient air at selected locations of Satna Satna city MP.

\section{MATERIAL AND METHODS}

Ambient air quality sampling was carried out from the five sampling stations covering gasoline station at Satna city. The sampling was done well above the prescribed height i.e. 1.5 meter and was free from any obstruction to flow of air.
All the sampling was done as per CPCB guideline. Sampling of BTX done with the help of Ecotech make Benzene sampler, Particulate matter sampling was done with the help of 'Envirotech APM-550' instrument and gaseous sampling was done with the help of Envirotech make APM 411. Duration of Sampling was 24 hours for Particulate matter 08 hours for gaseous pollutants sampling and $03 \mathrm{hrs}$ for BTX sampling. All the samples analyzed as per CPCB guidelines. BTX sample were analyzed using gas chromatograph (GC) fitted with capillary column and flame ionization detector (FID).

The main concern of the study was to measure the concentration of Benzene, Toluene and xylene, $\mathrm{PM}_{10}, \mathrm{PM}_{2.5}$, Sulphur dioxide, $\mathrm{NO}_{\mathrm{x}}$. The detail of sampling locations are given in Table-1 \& Fig: 1

Table-1: Showing details of sampling stations

\begin{tabular}{|c|l|l|c|l|}
\hline $\begin{array}{l}\text { Station } \\
\text { code }\end{array}$ & Station name & $\begin{array}{l}\text { Nearest petrol filling } \\
\text { Station }\end{array}$ & $\begin{array}{l}\text { Distance from } \\
\text { RS*(KM) }\end{array}$ & $\begin{array}{l}\text { Direction } \\
\text { from RS* }\end{array}$ \\
\hline A1 & Siddhartha nagar & Yadav Fuels & 2.8 & North East \\
\hline A2 & $\begin{array}{l}\text { Badripuram } \\
\text { Ramtekri }\end{array}$ & Sitaram Petrol Pump & 2.6 & East \\
\hline A3 & Semariya chauk & HP Petrol pump & 1.6 & North East \\
\hline A4 & Virat nagar road & Near Bharat Petroleum & 1.4 & North West \\
\hline A5 & Ramna tola & Near Indian Oil & 1.9 & South \\
\hline
\end{tabular}

RS*: Railway Station

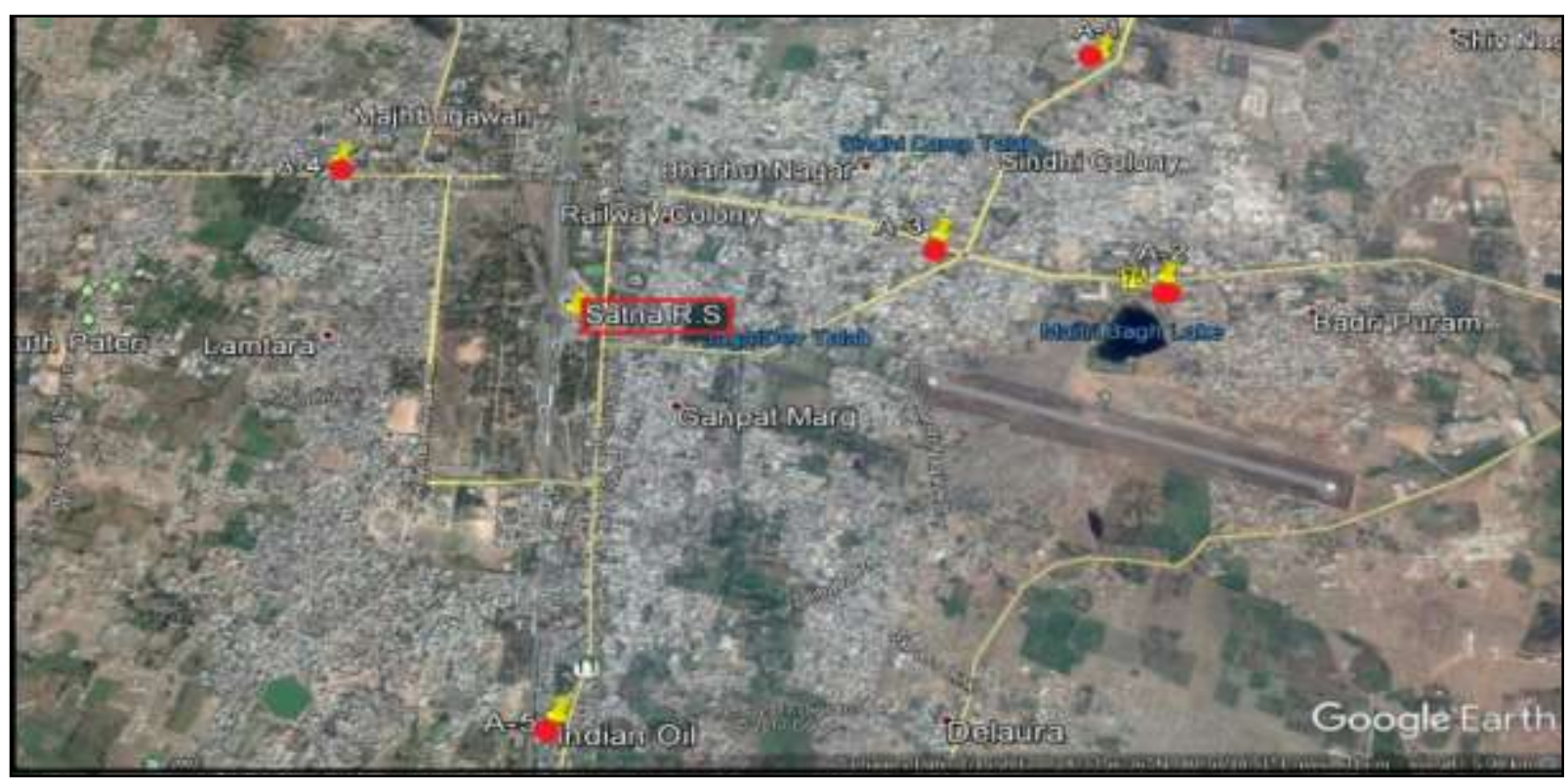

Fig-1: Map of Satna City showing Sampling Stations. 


\section{RESULTS AND DISCUSSION}

Ambient Air Quality was monitored at five sampling stations at monthly interval from
October to December 2016 and the obtained values are given in table- 2

Table-2: Ambient Air Quality Monitoring Results (October to December 2016)

\begin{tabular}{|c|c|c|c|c|c|c|c|c|c|}
\hline \multirow{2}{*}{$\begin{array}{l}\text { S. } \\
\text { No. }\end{array}$} & \multirow[b]{2}{*}{ Station } & \multirow[b]{2}{*}{ Month } & \multicolumn{7}{|c|}{ Parameters } \\
\hline & & & $\begin{array}{c}\text { Benzene } \\
\left(\mu \mathrm{g} / \mathrm{m}^{3}\right)\end{array}$ & $\begin{array}{l}\text { Toluene } \\
\left(\mu \mathrm{g} / \mathrm{m}^{3}\right)\end{array}$ & $\begin{array}{l}\text { Xylene } \\
\left(\mu \mathrm{g} / \mathrm{m}^{3}\right)\end{array}$ & $\begin{array}{c}\mathbf{P M}_{10} \\
\left(\mu \mathrm{g} / \mathbf{m}^{3}\right)\end{array}$ & $\begin{array}{c}\mathrm{PM}_{2.5} \\
\left(\mu \mathrm{g} / \mathrm{m}^{3}\right)\end{array}$ & $\begin{array}{c}\mathrm{SO}_{2} \\
\left(\mu \mathrm{g} / \mathrm{m}^{3}\right)\end{array}$ & $\begin{array}{c}\mathrm{NO}_{\mathrm{x}} \\
\left(\mu \mathrm{g} / \mathrm{m}^{3}\right)\end{array}$ \\
\hline \multirow{4}{*}{1} & \multirow{4}{*}{ A1 } & Oct'16 & 6 & 21 & 14 & 117 & 78 & 12 & 35 \\
\hline & & Nov'16 & 7 & 20 & 12 & 97 & 66 & 11 & 25 \\
\hline & & Dec'16 & 9 & 26 & 17 & 139 & 71 & 27 & 31 \\
\hline & & Average & 7.3 & 22.3 & 14.3 & 117.7 & 71.7 & 16.7 & 30.3 \\
\hline \multirow{4}{*}{2} & \multirow{4}{*}{$\mathrm{A} 2$} & Oct'16 & 5 & 18 & 11 & 86 & 54 & 21 & 36 \\
\hline & & Nov'16 & 6 & 21 & 9 & 124 & 73 & 23 & 32 \\
\hline & & Dec'16 & 9 & 34 & 15 & 146 & 79 & 17 & 27 \\
\hline & & Average & 6.7 & 24.3 & 11.7 & 118.7 & 68.7 & 20.3 & 31.7 \\
\hline \multirow{4}{*}{3} & \multirow{4}{*}{ A3 } & Oct'16 & 4 & 14.4 & 13 & 153 & 74 & 19 & 33 \\
\hline & & Nov'16 & 7 & 25 & 17 & 137 & 86 & 13 & 28 \\
\hline & & Dec'16 & 12 & 37 & 26 & 231 & 105 & 22 & 37 \\
\hline & & Average & 7.7 & 25.3 & 18.7 & 173.7 & 88.3 & 18.0 & 32.7 \\
\hline \multirow{4}{*}{4} & \multirow{4}{*}{ A4 } & Oct'16 & 8 & 26 & 14 & 98 & 65 & 14 & 26 \\
\hline & & Nov'16 & 9 & 28 & 17 & 145 & 79 & 10 & 23 \\
\hline & & Dec'16 & 11 & 32 & 18 & 178 & 81 & 16 & 29 \\
\hline & & Average & 9.3 & 28.7 & 16.3 & 140.3 & 75 & 13.3 & 26.0 \\
\hline \multirow{4}{*}{5} & \multirow{4}{*}{ A5 } & Oct'16 & 2 & 14 & 5 & 102 & 70 & 12 & 28 \\
\hline & & Nov'16 & 6 & 21 & 10 & 89 & 55 & 7 & 26 \\
\hline & & Dec'16 & 8 & 23 & 14 & 117 & 63 & 13 & 32 \\
\hline & & Average & 5.3 & 19.3 & 9.7 & 102.7 & 62.7 & 10.7 & 28.7 \\
\hline
\end{tabular}

Particulate Matter $\left(\mathbf{P M}_{10}\right): \mathrm{PM}_{10}$ was measured at all five selected stations. According to the national ambient air quality guidelines permissible limit for $\mathrm{PM}_{10}$ in ambient air is $100 \mu \mathrm{g} / \mathrm{m} 3$. The measured $\mathrm{PM}_{10}$ level was much higher than the suggested levels at most of the sampling station. The average concentrations of $\mathrm{PM}_{10}$ exceeded from the standards at all the stations (Table-2). The minimum concentration of $\mathrm{PM}_{10}$ was found $86 \mu \mathrm{g} / \mathrm{m}^{3}$ at A2 station in October'16 situated $2.6 \mathrm{KM}$ away in East direction from the railway station while at A3 the $\mathrm{PM}_{10}$ concentration was found highest i.e. $231 \mu \mathrm{g} / \mathrm{m}^{3}$ in December month.
At this station maximum traffic load, transportation activity takes place. Average values of $\mathrm{PM}_{10}$ at different stations are shown in Fig-3.

Particulate Matter ( $\left.\mathbf{P M}_{2.5}\right): \mathbf{P M}_{2.5}$ was measured at all five selected station. The permissible limit for $\mathrm{PM}_{2.5}$ in ambient air is $60 \mu \mathrm{g} / \mathrm{m}^{3}$ and most of the values observed higher than the permissible limit (Table-2). The concentration of $\mathrm{PM}_{2.5}$ was found minimum at A2 station $54 \mu \mathrm{g} / \mathrm{m}^{3}$ in Oct'16 and higher value was observed at A3 station i.e. $105 \mu \mathrm{g} / \mathrm{m}^{3}$ in Dec'16. Average concentration of $\mathrm{PM}_{2.5}$ at different station is shown in Fig-3. 
$\mathbf{S O}_{2}$ : Concentration of Sulphur dioxide was measured at all the five selected sampling stations in Oct'16 to Dec'16.The permissible limit for $\mathrm{SO}_{2}$ in ambient air is $80 \mu \mathrm{g} / \mathrm{m}^{3}$ and values observed for all the sampling stations were within the permissible limit. The minimum $\mathrm{SO}_{2}$ concentration was observed $7.0 \mu \mathrm{g} / \mathrm{m}^{3}$ at A5 Station on Nov'16 and maximum 27 $\mu \mathrm{g} / \mathrm{m}^{3}$ at A-1 on Dec'16 (Table-2). It may be because this station is near to Birla cement plant, Universal Cable Ltd. Fig; 4 shows $\mathrm{SO}_{2}$ average concentration at different stations.

NO $\mathbf{x}_{\mathbf{x}}$ : The permissible limit for $\mathrm{NO}_{\mathrm{x}}$ in ambient air is $80 \mu \mathrm{g} / \mathrm{m}^{3}$ and values observed for all the sampling stations were within the permissible limit. The minimum $\mathrm{NO}_{\mathrm{x}}$ was observed at A4 station $23 \mu \mathrm{g} / \mathrm{m}^{3}$ in Nov'16. Highest value was found $37 \mu \mathrm{g} / \mathrm{m}^{3}$ in December 2016 (Table-2). The values observed for all the stations were within the permissible limit $\left(80 \mu \mathrm{g} / \mathrm{m}^{3}\right)$ Average $\mathrm{NO}_{\mathrm{x}}$ at different stations are given in Fig-4.

Benzene: In Ambient Air concentration of benzene varied between $2-12 \mu \mathrm{g} / \mathrm{m}^{3}$. The permissible limit for Benzene in ambient air is $5 \mu \mathrm{g} / \mathrm{m} 3$. Lowest value was observed at A5 station in the month of Oct'16 and highest at A3 station in the month of Dec'16. Higher concentrations of Benzene were observed mostly at all the stations (Table-2). Average values of Benzene at different stations are shown in Fig- 2 . Higher occurrence levels of Benzene at said location could be due to low rate of dispersion, low mixing height at low temperature in winter season, attributed to varying traffic density, Out-door burn, evaporation of gasoline during filling process in addition to vehicular exhaust emission and incomplete combustion of gasoline compounds. Benzene is a toxicant carcinogenic compound therefore all the selected stations need immediate attention from health point of view.

Toluene: Toluene is chemically similar to Benzene. Concentration of Toluene in Ambient Air varied between $14-37 \mu \mathrm{g} / \mathrm{m}^{3}$ (Table-2). Lowest value was observed at A5 station in the month of Oct'16 and highest at A3 in the month of Dec'16. Average values of Toluene at different stations are shown in Fig-2.There are no standard for toluene in ambient air.

Xylene: Observed Xylene concentration was ranged between 5-26 $\mu \mathrm{g} / \mathrm{m}^{3}$ (Table-2). Lowest value was noted at A5 station in the month of Oct'16 and highest at A3 station near HP Petrol pump in the month of Dec'16. Average value of Xylene at various station are shown in Fig-2

\section{CONCLUSION \& RECOMMENDATION}

Monthly data for the study period October 2016 to December 2016, the benzene concentration was found higher than the permissible limit at most of the sampling station and need immediate attention. Particulate matter concentration respect to $\mathrm{PM}_{10}$ was higher than the permissible limit at most of the monitoring station. $\mathrm{PM}_{2.5}$ found on the verge of the limit at A2 and A5 in October and November respectively on other station it was also higher than the limit. Concentration of $\mathrm{SO}_{2}$ and $\mathrm{NO}_{\mathrm{x}}$ was found within the permissible limit.

There are many ways to reduce benzene and other common air pollutants in the environment, some are listed below-

- To organize Vehicle Inspection Programme.

- To follow the Industrial emission norms.

- To reduce unnecessary driving.

- Use public transportation, bike or walk. 


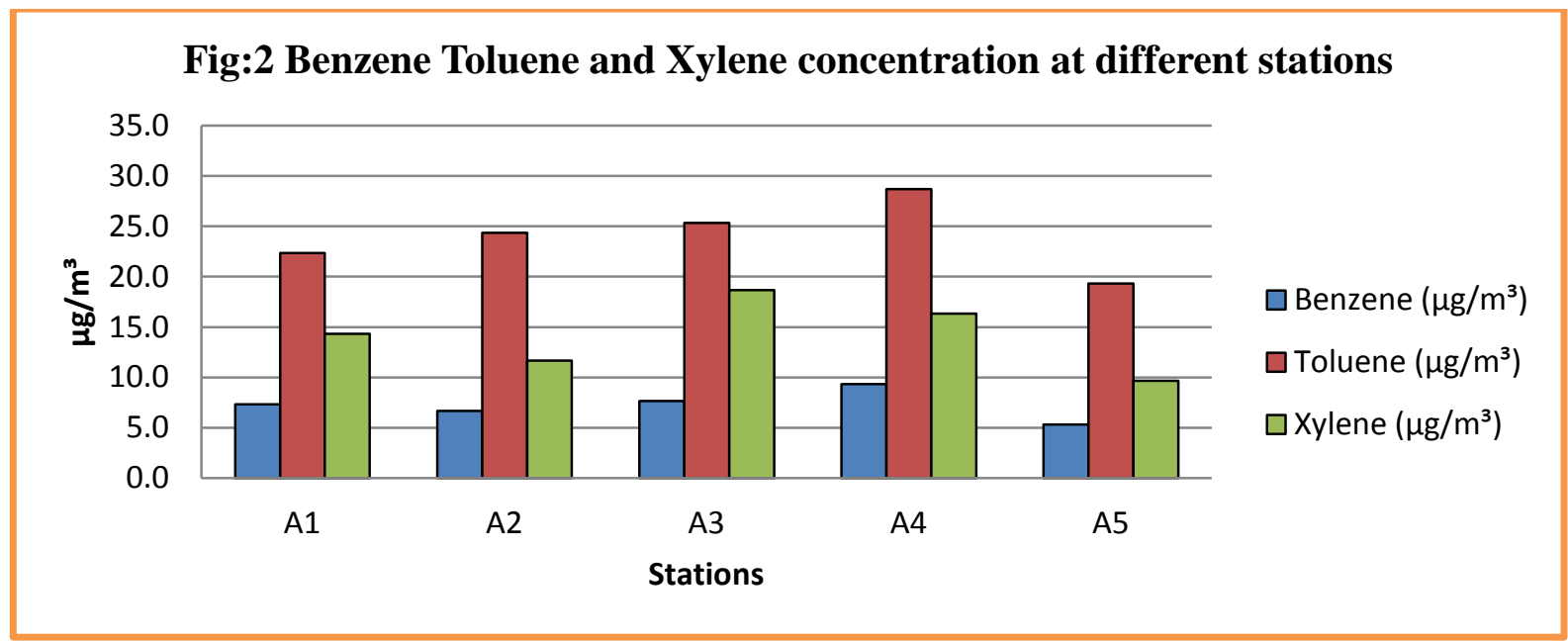

Fig:3 $\mathrm{PM}_{10}$ and $\mathrm{PM}_{2.5}$ Concentration at different stations

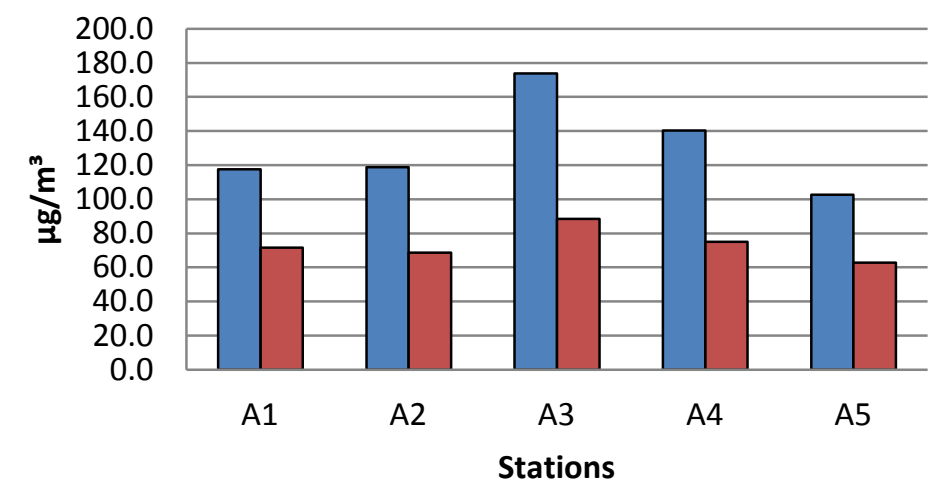

$\square \mathrm{PM} 10\left(\mu \mathrm{g} / \mathrm{m}^{3}\right)$

$\square$ PM2.5 $\left(\mu \mathrm{g} / \mathrm{m}^{3}\right)$

Fig: $4 \mathrm{SO}_{2}$ and $\mathrm{NO}_{\mathrm{x}}$ concentration at different stations

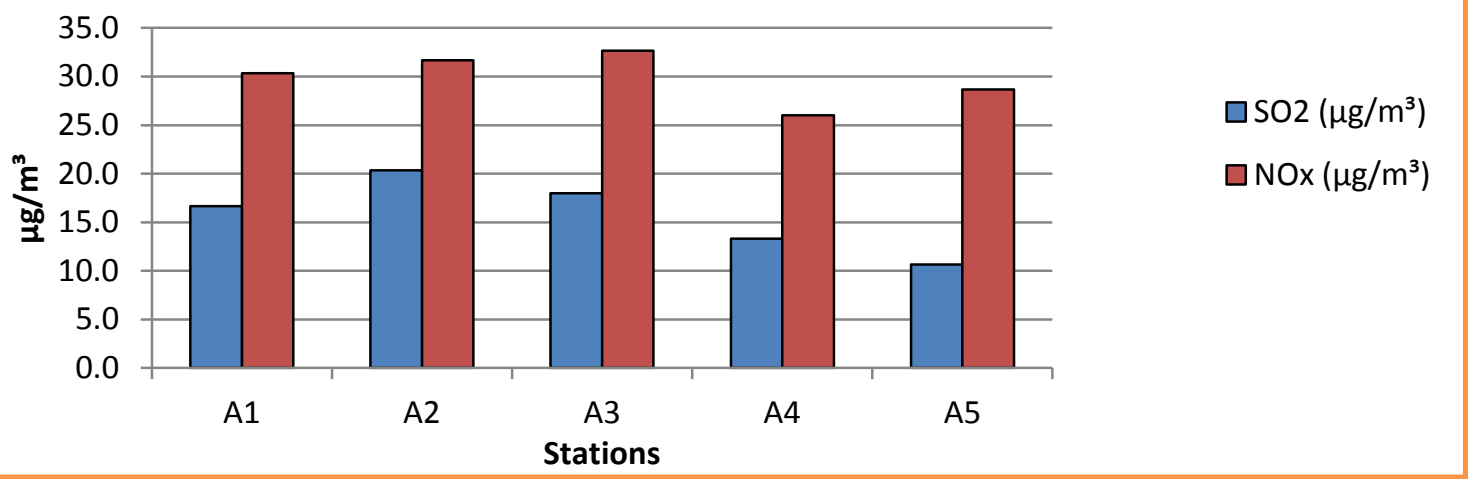




\section{REFERENCES}

1. Agrawal M. and Khanam N. (1997) Variatioin concentrations of particulate matter around a cement factory, Ind. J. Environ. Health, 392: 97-102.

2. Chaurasia S. and Tiwari A. (2016). Assessment of ambient air quality in the vicinity of cement industries, International Journal of Applied Research and Technology 1(1): 39-46

3. Chaurasia S., Karwaria A. and Gupta A. Dev (2013). Air pollution and air quality index of kodinar gujrat, India, International Research Journal of Environment Sciences 2(5): 62-67

4. Danab M. and Farrer D. (2011). Benzene in Oregon's air, Oregon Health Authority, State Of Oregon Department Of Environmental Quality, Fact sheet, DEQ 06-AQ-018a

5. Dubey B., Somvanshi S., Dhupper R. (2013). Air pollutants and their environmental impact: A review. International Journal of Advanced Research in Engineering and Applied Sciences, 2(5):33-42

6. Edokpolo B., Yu Q.J. and Connell D. (2014). Health Risk Assessment of Ambient Air Concentrations of Benzene, Toluene and Xylene (BTX) in Service Station Environments, International Journal of Environmental Research and Public Health,11:63546374

7. Eltahir M, Elgaali E. and Osman G. (2016). Characterization and potential health effects of exposing to vocs in petrol filling stations. International
Journal of Applied Research and Technology, 1(2): 64-83

8. Khan F.I. and Ghoshal A. K. (2000) Removal of volatile organic compounds from polluted air, Journal of Loss Prevention in the Process Industries, 13: 527-545

9. Rafieepour A, Shahna F.G, Hashemi Z, Ghamari F.(2012). Measurement of Benzene in air by Iranian single-wall carbon nanotubes, Iranian Journal of Toxicology, 5 (15):535-540

10. Saxena P. and Ghosh C. (2012). A review of assessment of Benzene, Toluene, Ethylbenzene and Xylene (BTEX) concentration in urban atmosphere of Delhi, International Journal of the Physical Sciences 7(6): $850-860$

11. Singh A.K., Tomer N. and Jain C.L.(2012). Monitoring, assessment and status of Benzene, Toluene and Xylene pollution in the urban atmosphere of Delhi, India, Research Journal of Chemical Sciences, 2(4):4549

12. U.S. Environmental Protection Agency, Office of mobile sources, Fact sheet OMS-2 (1995) Air toxics from motor vehicles EPA 400-F-92-004

13. Esmaelnejad F., Hajizade Y., Pourzamani H., Amin M.M (2015). Monitoring of benzene, toluene, ethyl benzene, and xylene isomers emission from Shahreza gas stations in 2013, International Journal of Environmental Health Engineering,4(1):1-7 